\title{
Preliminary analyses and amino acid profile of wild sunflower (Tithonia diversifolia) leaves
}

\author{
Ayodeji Oludare FASUYI ${ }^{*}$ and Femi James IBITAYO \\ Department of Animal Production \& Health Sciences, Faculty of Agricultural Sciences, \\ University of Ado-Ekiti, P.M.B. 5363, Ado-Ekiti, Ekiti State, Nigeria. \\ ${ }^{*}$ Corresponding author; E-mail: dejifasuyi@yahoo.com
}

\begin{abstract}
Tithonia diversifolia (wild sunflower) leaves were harvested, sundried and milled to obtain Tithonia diversifolia leaf meal (TDLM). Samples of the TDLM were analysed for proximate composition, amino acid profile and certain antinutrients. Analysis revealed a composition of $20.6 \% \mathrm{CP}, 18.9 \% \mathrm{CF}, 4.0 \% \mathrm{EE}, 42.5 \%$ $\mathrm{CHO}$ and $14.0 \%$ ash. Phytin was high at $79.10 \mathrm{mg} / 100 \mathrm{~g}$. Saponin, oxalate and alkaloids were also present at $2.36,1.76$ and $1.23 \mathrm{mg} / 100 \mathrm{~g}$, respectively. Tannin and flavonoid were in traces of 0.39 and $0.87 \mathrm{mg} / 100 \mathrm{~g}$, respectively. The contents of lysine, arginine, aspartate, glutamate, methionine+cystine, isoleucine, tyrosine and phenylalanine were remarkably high at 5.3, 6.19, 13.32, 12.19, 2.60, 4.28, 7.55, 3.53 and $5.47 \mathrm{~g} / 100 \mathrm{~g}$ protein. The ample presence of ANFs (phytins, oxalates, flavonoids and saponnins) portends a negative nutritional evaluation for TDLM as a potential non-ruminant feed ingredient. ANFs have been suggested as a probable militating factor hindering the digestibility of crude protein $(\mathrm{CP})$ and amino acids (AAs) in most plant products. The ample presence of some essential amino acids particularly isoleucine, leucine and lysine and other aromatic amino acids like phenylalanine and valine were remarkable suggestion of the potentiality of TDLM as a veritable alternative protein resource in non-ruminant feeding.

(C) 2011 International Formulae Group. All rights reserved.
\end{abstract}

Keywords: Antinutrients, potential protein resource, nutritional evaluation.

\section{INTRODUCTION}

The recognition of protein from leaf sources is fast gaining prominence because of its availability and perhaps, because it is the cheapest and the most abundant potential source of protein for animal nutrition (Fasuyi, 2007). The world wide shortage of animal protein sources, particularly in developing countries in Africa, has necessitated investigations of several novel protein sources for possible incorporation into animal feeds (particularly poultry) as replacements for the expensive conventional sources such as fish meal, groundnut cake and soybeans. The acute shortage of protein has been attributed to the phenomenal rise in the prices of animal feeds which account for about $75-85 \%$ of the recurrent production inputs in intensive monogastric animal production (Fetuga, 1977). Therefore, it is necessary to explore other less competitive plant resources and byproducts for use in monogastric nutrition, 
especially poultry. Wild sunflower (Tithonia diversifolia) is a green plant that originated from Mexico, and it is now widely distributed throughout the humid and sub-humid tropics in Central and South America, Asia and Africa (Sonka, 1997). Tithonia was probably introduced into Africa as an ornamental plant and can be found on roadsides and as invader of field crops in the forest savanna transition zones in Nigeria (Ayeni et al., 1997). Tithonia has been a subject of research interest because of the relatively high nutrient concentrations found in its biomass and because of its ability to extract relatively high amounts of nutrients from the soil. Tithonia diversifolia (wild sunflower) has been suggested as a potential green forage plant that can be utilized as feed stuff for animals due to its protein content (Farinu, 1986; Dutta et al., 1986).

This study therefore investigated the chemical, amino acids and antinutritional constituents in Tithonia diversifolia as a prelude to incorporation into non-ruminants feeds.

\section{MATERIALS AND METHODS}

Preparation of Tithonia diversifolia leaf meal (TDLM)

The test ingredients Tithonia diversifolia leaf meal (TDLM) was prepared by harvesting daily, the fresh and matured leaves of Tithonia diversifolia plants of different ages before flowering. The whole leaves were chopped manually using sharp knives, evenly sun dried for 4 days by regular turning using a rake. The chopped leaves were intermittently weighed to achieve $12-13 \%$ moisture content. Properly sun-dried TDLMs were stored in an air-tight container from which samples were periodically taken for laboratory analyses.

\section{Phytochemical screening of TDLM}

The extraction and precipitation of phytin in the fresh and dried leaves was done by the method of Wheeler and Ferrel (1971), while iron in the precipitate was determined as described by Makower (1970). Phytin was determined by using a $4: 6 \mathrm{Fe} / \mathrm{P}$ ratio to calculate phytin phosphorous and multiplying the phytin phosphorous by 3.55 as suggested by Young and Greaves (1940). Oxalate content was determined by the titrimetric method of Moir (1953) as modified by Ranjhan and Krishna (1980). Where extracts were intensely coloured, they were decolourised with activated charcoal (Balogun and Fetuga, 1980).

The polyphenols (tannic acid) was determined by extracting the dried and finely blended TDLM (250 mg in $10 \mathrm{ml}$ of $70 \%$ aqueous acetone) for $2 \mathrm{hrs}$ at $30{ }^{\circ} \mathrm{C}$ using Gallenkamp orbital shaker (Survey, UK). Pigments and fats were first removed from the leaves by extracting with di-ethyl ether containing $1 \%$ acetic acid. Thereafter, the total polyphenols (as tannic equivalent) were determined in $0.05,0.2$ or $0.5 \mathrm{ml}$ aliquot using Folin Ciocalteu (Sigma) and standard tannic acid $(0.5 \mathrm{mg} / \mathrm{ml})$ as described by Makkar and Goodchild (1996). Alkaloid determination was done using the method of Harbone (1973) while flavonoid determination was by the method described by Boham and KocipaiAbyazan (1974). Saponin content was assayed by the techniques of Rodriguez et al. (1986).

\section{Determination of proximate composition and amino acid profile of TDLM}

Proximate constituents of the TDLM (previously sun dried and milled to pass through $0.5 \mathrm{~mm}$ sieve) were determined by the method of Association of Official Analytical Chemist (AOAC, 1995). The amino acid profile was subsequently determined using methods described by Speckman et al. (1958). The TDLM sample was dried to constant weight, defatted, hydrolyzed, evaporated in a rotary evaporator and loaded into the Technicon Sequential Multi-Sample Amino acid Analyzer (TSM). 


\section{RESULTS}

Proximate composition and phytochemical screening of $T$. diversifolia leaf meal (TDLM)

Analysed TDLM contained $20.6 \% \mathrm{CP}$, $18.9 \% \mathrm{CF}, 4.0 \% \mathrm{EE}, 42.5 \% \mathrm{CHO}$ and $14.0 \%$ ash (Table 1). Phytin was noticeably higher than all other antinutrients (ANFs) at 79.10 $\mathrm{mg} / 100 \mathrm{~g}$. Saponin, oxalate and alkaloids were also present at 2.36, 1.76 and 1.23 $\mathrm{mg} / 100 \mathrm{~g}$, respectively. Other ANFs values were in traces of 0.39 and $0.87 \mathrm{mg} / 100 \mathrm{~g}$ for tannin and flavonoid, respectively (Table 2).

\section{Amino acid profile of TDLM}

Amino acid profile is shown on Table 3. The contents of lysine, arginine, aspartate, glutamate, methionine+cystine, isoleucine, tyrosine and phenylalanine were appreciably high at $5.3,6.19,13.32,12.19,2.60,4.28$, $7.55,3.53$ and $5.47 \mathrm{~g} / 100 \mathrm{~g}$ protein.

Table 1: Proximate Composition of Fresh/Dried T. diversifolia Leaves (\% dry matter).

\begin{tabular}{lc}
\hline Nutrient & Percentage Composition \\
\hline Moisture & $11.0 \pm 0.01$ \\
Crude Protein & $20.6 \pm 0.03$ \\
Crude fibre & $18.9 \pm 0.10$ \\
Ether extracts & $4.0 \pm 0.01$ \\
Carbohydrate & $42.5 \pm 0.10$ \\
Ash & $14.0 \pm 0.02$ \\
\hline \multicolumn{2}{c}{ Values are means of 3 determinations \pm SEM. }
\end{tabular}

Table 2: Composition of Antinutrients (mg/100 g) in T. diversifolia leaves.

\begin{tabular}{lc}
\hline Antinutrients & Concentration $(\mathbf{m g} / \mathbf{1 0 0} \mathbf{g})$ \\
\hline Phytin & $79.10 \pm 0.09$ \\
Tannin & $0.39 \pm 0.01$ \\
Oxalate & $1.76 \pm 0.02$ \\
Saponin & $2.36 \pm 0.01$ \\
Alkaloid & $1.23 \pm 0.03$ \\
Flavonoid & $0.87 \pm 0.02$ \\
\end{tabular}

Values are means of 3 determinations \pm SEM. 
Table 3: Amino Acid Profile of TDLM Compared with Groundnut Cake, Whole Egg and FAO/WHO Recommended Pattern (g/100 g protein).

\begin{tabular}{lcccc}
\hline Amino Acids & ${ }^{* \text { TDLM }}$ & ${ }^{\mathrm{a}} \mathbf{G N C}$ & $\begin{array}{c}{ }^{\mathrm{b}} \text { Hen's whole } \\
\text { egg }\end{array}$ & FAO/WHO \\
\hline Lysine & 5.35 & 3.80 & 3.94 & 3.44 \\
Histidine & 2.25 & 2.40 & 1.50 & - \\
Arginine & 6.19 & 11.00 & 3.81 & - \\
Aspartic acid & 13.32 & - & - & - \\
Threonine & 4.26 & 2.80 & 3.19 & 2.50 \\
Serine & 5.13 & - & - & - \\
Glutamic acid & 12.19 & - & - & - \\
Proline & 3.91 & - & - & - \\
Glycine & 5.09 & 6.00 & 6.00 & - \\
Alanine & 6.08 & - & - & - \\
Valine & 5.29 & 5.20 & 4.75 & 3.13 \\
Methionine & 1.56 & 1.10 & 2.00 & - \\
Cystine & 1.04 & 1.60 & 1.13 & - \\
Meth. + Cys. & 2.60 & 2.70 & 3.13 & 2.19 \\
Isoleucine & 4.28 & - & 3.50 & 2.50 \\
Leucine & 7.55 & 6.50 & 5.19 & - \\
Tyrosine & 3.53 & 3.90 & 2.50 & 3.75 \\
Phenylalanine & 5.47 & 5.20 & 3.19 & - \\
\hline
\end{tabular}

*TDLM, Tithonia diversifolia leaf meal, amino acid profile was determined using methods described by Speckman et al (1958). ${ }^{a}$ Amino acid profile for G/nut meal was adopted from Ravindran and Blair (1992). ${ }^{b}$ Amino acid profile for hen's whole egg was cited by Robinson (1987). FAO/WHO and whole egg amino acid profiles were finally converted to $\mathrm{g} / 100 \mathrm{~g}$ from initial unit of $\mathrm{g} 16 \mathrm{~g}^{-1} \mathrm{~N}$ by Robinson (1987) before converted to $\mathrm{g} \mathrm{kg}^{-1}$ and cited by Fasuyi (2006). GNC is groundnut cake.

\section{DISCUSSION}

Proximate composition and phytochemical screening of TDLM

The $20.6 \%$ CP obtained for analysed TDLM was appreciable and at face value qualifies TDLM as a potential plant protein source in livestock nutrition. This quantity was higher than $18.9 \% \mathrm{CP}$ reported by Olayeni et al. (2006). It was also higher compared to other leaf meals like Colliandra $s p(18.9 \% \mathrm{CP})$, Alfalfa leaf meal $(20.0 \% \mathrm{CP})$ and sweet potato leaf meal (14.0\% CP) (Katto and Salazar, 1995). The above variation in the concentration of nutrients in $T$. diversifolia can conceivably be influenced by plant part, age of plant, position of the leaf within the plant canopy, soil fertility and provenance (Jama et al., 2000). The low fat content of $4.0 \%$ recorded for TDLM in this study may be a nutritional advantage in farm animal nutrition as higher fat contents in feed ingredients have been reported to be the probable causes of retardation of normal digestion and metabolism (Atteh, 2002). The crude fibre content was appreciably high at $18.9 \%$ and calls for nutritional concern, especially when considering TDLM as a potential ingredient in monogastric feeds. This level may be a hindrance to the bioavailability of other nutrients, intestinal irritation, feed bulkiness and overall decreased nutrient utilization (Fasuyi and Nonyerem, 2007).

The major antinutrients in TDLMs (phytin, tannin, oxalate, alkaloid and flavonoid) in this study had higher levels compared to previous report by Fasuyi et al. (2010). Fasuyi et al. (2010) suggested that the antinutrients in TDLM can be further reduced when TDLM is subjected to ensiling with molasses addition. The presence of some 
anitnutritional factors (ANFs) in TDLMs is of negative nutritional relevance. The ample presence of ANFs (phytins, oxalates, flavonoids and saponnins) portends a negative nutritional value on the bioavailability of TDLM in animal nutrition. These ANFs have been suggested as probable factor that militated against the digestibility of crude protein (CP) and amino acids (AAs) in most plant products. Phytic acid levels in the TDLMs were high and similar to those earlier reported (Proll et al., 1998). When ingested by non-ruminants, phytic acid can bind with proteins to form phytate protein complexes (Saio et al., 1967). This complex can adversely affect the digestibility of proteins (Reddy et al., 1982) by inhibiting a number of digestive enzymes in the gastrointestinal tract. ANFs have been reported as having inhibiting effects on the digestive enzyme activity in chickens and rats (Longstaff and Mcnab, 1991; Welsch et al., 1989). Meanwhile, the high saponin content of the seed may potentiate it as an aphrodisiac.

\section{Amino acid profile of TDLM}

Amino acid profile indicates that TDLM is rich in some essential amino acids, particularly isoleucine, leucine and lysine; also rich in aromatic amino acids like phenylalanine and valine when compared with amino acid profiles of commonly used conventional protein sources like groundnut cake. The comparison with whole egg and FAO/WHO recommended pattern also indicated a fairly balanced amino acid profile.

The abundant protein in some green leaves (Fasuyi and Aletor, 2005), could be attributed to the ability of green leaves to synthesize amino acids from a wide range of virtually unlimited and readily available primary material such as water, carbondioxide and atmospheric nitrogen. Utilization may however be hindered by the presence of anti-nutritional factors (Fasuyi and Aletor, 2005). However, there seemed to be a deficiency in the quantities of histidine, arginine, glycine and tyrosine when compared to that of groundnut.

\section{Conclusion}

With the overwhelming possibility of reducing the antinutritional factors in TDLM by bio-fermentation and other processing techniques, TDLM can be considered a potential plant protein source in livestock feeding particularly in monogastric animals which naturally compete with man for conventional food/feed materials. With its rich amino acid profile, TDLM can be further processed and investigated in feeding trials for various categories of farm livestock.

\section{REFERENCES}

AOAC (Association of Official Analytical Chemists). 1995. Official Methods of Analysis (16 ${ }^{\text {th }}$ edn). Washington D.C.

Ayeni AO, Lordbanjou DT, Majek BA. 1997. Tithonia diversifolia (Mexican sunflower) in South-Western Nigeria: Occurrence and growth habit. Weed Research (Oxford), 37: 443-449.

Atteh JO. 2002. Principles and Practice of Livestock Feed Manufacturing. ADLEK Printers: Ilorin, Nigeria.

Balogun AM, Fetuga BL. 1980. Tannin, phytin and oxalate content of some wild under-utilized crop seeds in Nigeria. Food Chem., 30: 37-43.

Boham BA, Kocipai-Abyazan R. 1974. Flavonoids and condensed tannins from leaves of Hawaiian vaccinium vaticulatum and $V$. calycinium. Pacific Sci., 48: 458-463.

Dutta P, Bharatacharyya PR, Rabha IC, Bordolon ON, Barna NC, Chowdurry PK, Sharma PR, Barna JN. 1986. Feeding deterrents for philosamiaricini (Samia cynthia, Subrp. Ricins) from Tithonia diversifolia. Phytoparasitica, 14: 77-80.

FAO/WHO. 1973. Energy and protein requirements. Technical Report Series No. 52:1-118 Geneva, Switzerland.

Farinu GO. 1986. Chemical composition of some plant products of the savannah 
forest zone of Nigeria. Food Chem., 22: 315-320.

Fasuyi AO, Aletor VA. 2005. Varietal composition and functional properties of cassava. (Manihot esculenta, Crantz) leaf meal and leaf protein concentrates. Pakistan Journal of Nutrition., 4(1): 4349.

Fasuyi AO. 2006. Bio-nutritional evaluations of three tropical leaf vagetables (Telfairia occidentalis, Amaranthus cruentus and Talinum triangulae) as sole dietary protein sources in rat assay. Food Chem., 103: $757-765$.

Fasuyi AO. 2007. Amaranthus cruentus leaf meal as a protein supplement in broiler finisher diets. Part 1. performance and nitrogen utilization. African Journal of Food, Agriculture, Nutrition \& Development 7(6).

Fasuyi AO, Nonyerem AD. 2007. Biochemical, nutritional and haematological implications of Telfairia occidentalis leaf meal as protein supplement in broiler starter diets. African Journal of Biotechnology, 6(8): 1055-1063.

Fasuyi AO, Dairo FAS, Ibitayo FJ. 2010. Ensiling wild sunflower (Tithonia diversifolia) leaves with sugar cane molasses. Livestock Research for Rural Development, 22(3). www.lrrd.org/ lrrd22/fasu22042.htm

Fetuga BL. 1977. Animal production in Nigeria, and feed supplies. Nig. J. Ani. Prod., 4(1): 19-41.

Jama, B, Palm CA, Buresh RJ, Niang A, Gachengo C, Nziguheba G, Amadalo B. 2000. Tithonia diversifolia as a green manure for soil fertility improvement in western Kenya: A review. Agro-forestry Systems, 49: 201-221.

Katto CIR, Salazar A. 1995. Boton de oro (Tithonia diversifolia (Hemsl) Gray) una fuente proteica alternativo para el tropic. Livestock Research for Rural Development. 3(6).
Longstaff M, Mcnab JM. 1991. The inhibitory effects of hull polysaccharides of field beans (Vicia faba L.) on the digestion of amino acids, starch and lipids and on digestive enzyme activity in young chicks. British Journal of Nutrition, 65: 199.

Makkar AOS, Goodchild AV. 1996. Qualification of Tannins. A laboratory manual. International Centre for Agriculture Research in Dry Areas (ICARDA), Aleppo, Syria, IV 25.

Makower RV. 1970. Extraction and determination of phytic acid in beans (Phaseolus vulgaris). Cereal Chem. 47: 288-292.

Moir KW. 1953. The determination of oxalic acid in plants. Queensland J. Agric. Sci., 10(1): 1-3.

Olayeni TB, Farinu GO, Togun VA, Adedeji OS, Aderinola AO 2006. Performance and Haematological Characteristics of Weaner Pigs Fed Wild Sunflower (Tithonia diversifolia Hemsl A Grey) Leaf Meal.Department of Animal production and Health, P.M.B. 4000, Ladoke Akintola University of Technology, Ogbomoso, Nigeria. Journal of Animal and Veterinary Advances, 5(6): 499-502.

Proll JK, Petzke J, Ezeagu IE, Metges OC. 1998. Low nutritional quality of unconventional tropical crop seeds in rats. Journal of Nutrition, 128: 2014-2022.

Ranjhan SR, Krishna G. 1980. Laboratory Manual for Nutrition Research, eds S.R. Ranjhan \& G. Krishna Vikas Pub. Co: New Delhi, India.

Ravindran V, Blair R. 1992. Feed resources for poultry production in Asia and the Pacific. II Plant Protein Sources. World Poultry Sci. Journal, 48: 205 - 231.

Reddy NR, Sathe SK, Salunkhe DK. 1982. Phytates in legumes and cereals. Advance Food Nutrition Research, 28: 1-92.

Robinson DS. 1987. Protein Sources. In Important Amino Acids of Some Animal Foods $\left(1^{\text {st }}\right.$ ed., Food Biochemistry and 
Nutrition Value, pp 147). Longman Scientific and Technical: UK.

Rodriguez L, Boland JAV, Garayzabal JFF, Tranchant P, Gomez - Lucia E, Ferri EFR, Fernandez GS. 1986. Microplate technique to determine haemolytic activity for routine typing of Listeria Strains. J. Clin. Micro., 24: 99-103.

Saio K, Koyama E, Watanabe T. 1967. Protein-calcium-phytic acid relationship in soybean. 1. Effects of calcium and phosphorus on solubility characteristics of soybean meal protein. Agricultural Biology \& Chemistry, 31: 110-115.

Sonka D. 1997. Tithonia weed - A potential green manure crop. Echo Development Notes, 57: 5-6.

Speckman DH, Stein WH, Mooer S. 1958. Automatic recording apparatus (amino acid analyser used in the extraction of non-protein nitrogen from potato tuber and its amino acids. www.springerlink. com/index/970273P2.

Welsch CA, Lachance PA, Wasseman BP. 1989. Effects of native and oxidized phenolic compounds on sucrase activity in rat brush-border membrane vesicles. Journal of Nutrition, 11: 1737-1740.

Wheeler EL, Ferrel RE. 1971. A method for phytic acid determination in wheat fractions. Cereal Chem., 48: 312-316.

Young SM, Greaves JS. 1940. Influence of variety and treatment on phytic acid content of wheat. Food Res., 5: 103-105.

Ravindran V, Ravindran G. 1988. Nutritional and antinutritional characteristics of Mucuna (Mucuna utilis) bean seeds. J. Sci. Food Agric., 46: 71-79. 